\title{
The marine epilithic diatom Melosira brandinii sp. nov. (Bacillariophyta) from Elephant Island, Antarctic Peninsula, with comments on some related species
}

\author{
Luciano F. Fernandes ${ }^{1} \&$ Roseli M. de Souza-Mosimann ${ }^{2}$ \\ ${ }^{1}$ Universidade Federal do Paraná, Departamento de Botânica \\ Setor de Ciências Biológicas, Centro Politécnico \\ (Caixa Postal 19031, 81531-970, Paraná, PR, Brasil) \\ e-mail: lucfel@bio.ufpr.br \\ ${ }^{2}$ Horto Botânico - Universidade Federal de Santa Catarina \\ Campus Universitário, Trindade \\ (Caixa Postal 476, 88010-970 Florianópolis, SC, Brasil)
}

- Abstract: A new species of epilithic diatom is described from samples collected near Elephant Island, Antarctic Peninsula. The cells of Melosira brandinii sp. nov. are joined in filamentous chains and attached by means of long mucilaginous stalks. The valves are circular with the valvar surface composed of irregularly arranged pentagonal loculi. Each loculus bears 6-12 pores on the external surface, opening to the innerside through rotae. The corona is only composed of coarse granules. A mantle is well developed, presenting rimoportulae and bearing coarse granules, which are more concentrated at the mantle edge. Comparisons with the related species Melosira arctica, M. moniliformis and M. nummuloides are made. Additionally, photomicrographs of $M$. arctica from the type material and Barents Sea, and of M. moniliformis from estuaries of Southern Brazil are included.

- Resumo: Uma nova espécie de diatomácea eplítica é descrita sob microscopia eletrônica, a partir de amostras coletadas próximo à Ilha Elefante, Península Antártica. As células de Melosira brandinii sp. nov. encontram-se reunidas em cadeias filamentosas através de longos tubos mucilaginosos. As valvas são circulares, com superfície valvar provida de lóculos pentagonais arranjados irregularmente. Cada lóculo possui 6-12 poros na superfície externa, abrindo-se para o interior através de aréolas do tipo rota. A corona é composta exclusivamente por grânulos grosseiros, os quais estão mais concentrados na borda do manto. Comparações com as espécies próximas Melosira arctica, M. moniliformis e M. nummuloides foram realizadas. Adicionalmente, são fornecidas fotomicrografias de $M$. arctica provenientes do material tipo e do Mar de Barents (Ártico), e de M. moniliformis de estuários do Sul do Brasil.

- Descriptors: Melosira brandinii, Diatom, Taxonomy, Antarctic Peninsula, Antarctica.

- Descritores: Melosira brandinii, Diatomácea, Bacillariophyta, Bentos, Península Antártica.

\section{Introduction}

The genus Melosira C. A. Agardh includes estuarine [M. moniliformis (Müller) C. A. Agardh, $M$. nummuloides (Dilllwin) C. A. Agardh] and freshwater representatives ( $M$. varians $\mathrm{C}$. A. Agardh). Most of the taxa are benthic, and may comprise an important fraction of the algal biomass in bottom communities (Round et al., 1990, Rendall \& Wilkinson 1983, Ferreira \& Seeliger, 1985). The genus is characterized by the presence of typical loculate structure with small pores, opening to the interior by means of rotae. The valvar face is bordered by a corona. The prominent mantle has a marginal ring of rimoportulae at the edge, and the bands of the cingulum are ligulate and perforated by pores (Crawford, 1975, Round et al., op.cit.). Cells are also joined in chains by means of mucilage or siliceous structures located near the center of the valve (Crawford, 1979). Morphological studies of different taxa under the electron microscope elucidated many taxonomic problems concerning the genus Melosira; for instance, the description of a special loculate valve structure, the position of the rimoportulae and the characteristics of the cingulum (Crawford, 1971, 1974, 1975, 1977, 1978, 1979). These findings led to the proposal of new genera for those taxa that did not fit the circumscription of 
Melosira C. A. Agardh (Simonsen, 1979, Round et al., 1990). Classical and recent contributions to the taxonomy of Melosira species from polar regions (Cleve, 1883, Mangin, 1915, Heiden \& Kolbe, 1928, Hustedt, 1958, Karsten, 1906, Manguin, 1960, Van Heurck, 1909) provided important data related to the description of new species and their distribution, but only using light microscope techniques. Of these, only the arctic marine species, $M$. arctica (Ehrenberg) Dickie, has been investigated using electron microscopy (Heimdal, 1973, Syvertsen \& Hasle, 1988).

In this work we describe a new species of Melosira found in epilithic samples collected near Elephant Island, Antarctic Peninsula during the XIII Brazilian Expedition to Antarctica in 1994. In addition, we compare this new species with the related taxa, $M$. arctica, $M$. moniliformis and $M$. nummuloides.

\section{Material and methods}

Samples were collected near Elephant Island $\left(61^{\circ} 14^{\prime} \mathrm{S}, 55^{\circ} 08^{\prime} \mathrm{W}\right)$, Antarctic Peninsula, in late November 1994, during the XIII Brazilian Antarctic Program (PROANTAR XIII). Material was removed from intertidal rocks using a spatula. Water temperature varied from $0.4^{\circ} \mathrm{C}$ to $2.0^{\circ} \mathrm{C}$, and salinity from 33.5 to 34.2 . One aliquot was preserved in formaldehyde $(2 \%)$ for microscopic analysis and preparation of slides. Another aliquot was prepared for in vivo observations of the cells of Melosira and the associated community by carefully placing some colonies into Utermöhl chambers designed for the inverted microscope.

In order to compare the new species with related taxa, we analyzed material containing $M$. moniliformis from Paranaguá Bay, Southern Brazil $\left(25^{\circ} 27^{\prime} \mathrm{S}, 48^{\circ} 20^{\prime} \mathrm{W}\right)$, sampled in November 1995 , when the water temperature varied between $20^{\circ} \mathrm{C}$ and $28^{\circ} \mathrm{C}$, and salinity from 19 to 28 . Material containing M. arctica was sampled on the undersurface of $2.5 \mathrm{~m}$ thick ice in the Barents Sea $\left(82^{\circ} 15^{\prime} \mathrm{N}, 25^{\circ} 51^{\prime} \mathrm{E}\right.$, PROMARE, 2-Aug.-1984). Also, photomicrographs of $M$. arctica type material (Melville Bay, Canadian Arctic, Dickie's sample) were kindly made available by Drs G. R. Hasle and E. E. Syvertsen (University of Oslo, Norway).

Samples were processed for microscopy according to Hasle \& Fryxell (1970). Permanent slides for examination by light microscopy (LM, Olympus mod. BX40) were prepared using Naphrax as the mounting medium. For observation with the scanning electron microscope (SEM), cleaned samples were placed directly onto aluminum stubs, air dried, and covered with $16-20 \mathrm{~nm}$ gold. In order to preserve fragile structures (mucilage stalks and cingulum) and to study entire frustules, some material was critical-point dried using $\mathrm{CO}_{2}$, after dehydration in ethanol. A Phillips XL30 electron microscope was used under $10-30 \mathrm{kV}$ acceleration voltage. Terminology for description of valve structure follows Ross et al. (1979) and Round et al. (1990).

\section{Results}

Melosira brandinii L. F. Fernandes et R. M. SouzaMosimann sp. nov.

Latin Diagnosis: Cellulae componentes filamenta, juncta per strigatus tubos ex mucilagine constantes. Valvae circulares exhibentes loculi pentagonales, irregulariter dispositas, portantes 6-12 poros externa in superficie, aperientes se ad interiorem per rotae. Rimoportula exhibens aperturam circularem, aperiens se ad interiorem, per fissuras longulas, sine spissitate circulari. Corona composita solum granulis. Mantum exhibens solum rimoportulae et granula grossa. Annulus marginalis e rimoportulis factus, exhibens 10-12 rimoportulae per $10 \mathrm{\mu m}$. Diametrum valvaris 20-62 $\mu \mathrm{m}$ longus; axis pervalvaris 34-76 $4 \mathrm{~m}$ longus.

Diagnosis: Cells joined in filaments by striated mucilage stalks. Valves circular with irregularly arranged pentagonal loculi. Loculus with 6-12 pores on the external surface, opening to the inside through radially arranged rotae. Rimoportulae with circular apertures opening to the interior by means of elongated fissures lacking circular thickenings. Corona composed of granules only. Mantle with rimoportulae and coarse granules only. Marginal ring of rimoportulae with 10-12 rimoportulae per $10 \mu \mathrm{m}$. Valvar diameter 20-62 $\mu \mathrm{m}$, pervalvar axis 34-76 $\mu \mathrm{m}$.

Holotype: slide n. 12760, FLOR Herbarium at Federal University of Santa Catarina (UFSC), Brazil

Type locality: Elephant Island $\left(61^{\circ} 14^{\prime} \mathrm{S}, 55^{\circ} 08^{\prime} \mathrm{W}\right)$ Antarctic Peninsula, on intertidal rocks. Water temperature $0.5-2.0^{\circ} \mathrm{C}$, salinity 34.2 .

Etymology: Homage to Dr Frederico P. Brandini (Centro de Estudos do Mar, Universidade Federal do Paraná), for his efforts to improve the research on phytoplankton ecology in Brazil.

Description LM: Colonies are hemispherical, 2$3 \mathrm{~cm}$ in diameter and brownish. Cells are joined in filamentous chains by short to long mucilage stalks, to which other diatoms may attach (Fig. 1). Cells are cylindrical with convex margins (Fig. 2). Plastids are 
discoid, parietal and numerous. Mucilage stalks are secreted from the valve face, are in variable length (the longest serving to adhere colonies to the substratum) and show longitudinal striations on their surface (Fig. 2). Frustules are united into doublets or triplets with a common cingulum, creating a triangular pseudosulcus with concave sides (Fig. 2). The valve is circular, slightly convex (domed) to deeply hemispherical with a flat valvar face (Figs 4, 10). Valvar diameter is $20-62 \mu \mathrm{m}$ (mostly more than $40 \mu \mathrm{m}$ ), pervalvar axis is $34-76 \mu \mathrm{m}$. The valve face has the circular openings of rimoportulae scattered over its surface, appearing as refringent points on the mantle (Figs 6-8). A poorly developed corona composed of numerous refringent granules borders the valve face (Fig. 7), and there is no carina. The valvar faces of lightly silicified valves are smaller than those of heavily silicified ones. Figure 9 shows an uncompletely formed valve, where a ring of silica (annulus) is visible around the central area. The valvar surface is loculate, each loculus being polygonal in shape. The margin of the mantle is well marked in larger cells, but discernible with difficulty in smaller ones. Bands of cingulum are open (Fig. 5), bearing transverse rows of pores bordered by a narrow silica strip on each side. Auxospores are terminal, ellipsoid to spherical (Fig. 3).

Description SEM: The frustules (Figs 13-14) are joined in filamentous chains through mucilage stalks situated at the centre of the valve face (Figs 13-15). Here, mucilage appears as a ring that may extend to the valve mantle. The valvar surface is weakly convex to hemispherical, separated into valve face and mantle. The valve face contains apertures of rimoportulae (Figs 16-17) and a loculate valvar wall, which are less conspicuous on the valve face than the mantle. Each loculus is pentagonal in shape (at times quadrangular) with 6-12 small pores on the external surface, bordered by silica ridges (Fig. 19). The loculus opens internally via 2 or more rotae (Figs 17 18). Each rota is divided by a silica bar with or without a circular thickening at the center. The radial arrangement of the rotae is more evident towards the margin (Figs 17-18). At the center, rotae are scarce (Fig. 17). A discrete corona of broad granules appears around the valvar face (Fig. 16). The mantle bears loculi, rimoportulae and coarse granules scattered over its surface (Figs 15, 19-20) and a ring of rimoportulae at the mantle edge, $10-12$ in $10 \mu \mathrm{m}$ (Figs 19-20). The rimoportula consists of an external circular aperture encircled by a delicate rim (Figs 1920 ), and an internal elongated and sessile fissure (Figs 17-18). No defined pattern of the fissures was observed. The rimoportulae are more numerous at the center (Fig. 16) than in the rest of the valve.
There are 2-8 open cingular bands in complete frustules and all but the valvocopula are ligulate (Figs 13-14, 21). Each band is perforated by transverse rows of circular to elongated pores (6-8 per row) (Figs 20-21), with a solid longitudinal silica strip around its entire margin (Fig. 20). Some pores were recorded outside of the strip. The ligulae are triangular. Figure 22 shows an internal view of a valvocopula, in which a rectangular thickening emerges, connecting the cingulum to the flange of the valvar margin.

Preauxospore cell. The preauxospore cell (pervalvar axis 20.0-21.5 $\mu \mathrm{m}$, diameter 8.5-9.0 $\mu \mathrm{m}$, rarely $12 \mu \mathrm{m}$ ) shows a strongly convex valvar surface (Figs 10-12). It bears loluli in radial rows and a smalier number of rimoportulae than larger cells. A marginal ring of rimoportulae occurs at the mantle edge (Fig. 23). The cingulum is more sharply modified, when compared to larger cells. The pores of the first and second bands are frequently arranged in irregular rows, and their number is smaller than in larger valves. In the third and fourth bands (Fig. 23), the pores are elongated and reach to the band edge, where they appear eroded. These bands also seem to be fused one to another, masking the limits between epicingulum and hipocingulum. Many preauxospores examined in our material exhibited the cingulum characteristics described above.

\section{Discussion}

On superficial observation, the valves of $M$. brandinii are easily confused with $M$. moniliformis. However, closer examination reveals important differences. Loculi of $M$. brandinii are pentagonal and have fewer pores, whilst $M$. moniliformis bears hexagonal loculi and numerous pores perforating the siliceous wall (Fig. 25 and Crawford, 1977). Moreover, in the latter species the rotae bars tend to be arranged along the valvar radii (Crawford, 1977). On the other hand, the orientation of the rotae of $M$. brandinii is irregular. In both the species rotae are arranged in radial rows over the mantle surface.

Although the rimoportulae are arranged on a similar pattern over the surface in the two species, the labiate slit internally and the circular thickening around the external opening of the rimoportulae of $M$. moniliformis (Fig. 36 and Crawford, 1977) are absent in $M$. brandinii, in which the rimoportulae are sessile and lack a circular thickening. Crawford (1977) also observed that the labiate structures of rimoportulae in $M$. moniliformis tend to be oriented along the mantle radius; such a pattern is absent in $M$. brandinii. The marginal ring of rimoportulae at the mantle edge is another diagnostic feature. $M$. brandinii has 10-12 
rimoportulae in $10 \mu \mathrm{m}$, but there are only 4-6 rimoportulae in $M$. moniliformis (present work; Fernandes et al., 1999).

Three other types of ornamentation are present on the valvar surface of $M$. moniliformis: spines, broad granules with rounded apices, and small granules (Figs 24-26). Spines and broad granules are robust in this species, and their bases are formed by thickenings arising from the silica ridges of loculi (Fig. 25). Moreover, the small granules are hemispherical and scattered on the valve surface. On the other hand, in $M$. brandinii spines and small granules are lacking, only broad granules occur with rounded apices, but without thickened bases. All these features give a more delicate aspect to the valve of $M$. brandinii.

The corona is another distinctive feature differentiating the new species from other related taxa. The structure is only weakly developed in $M$. brandinil, that is, it is composed of granules more or less grouped around the valve face, but not forming an elaborate structure as the robust spines or a continuous silica membrane observed in $M$. moniliformis and $M$. arctica (Crawford, 1977, Syvertsen \& Hasle, 1988, Fernandes et al., 1999).

The cingulum of $M$. brandinii also shows specific characters. Pores are arranged in transverse rows and encircled by peripheral hyaline strips on both edges of the bands. Moreover, some pores were recorded on the external side of the strips. In $M$. moniliformis, the hyaline strip is restricted to the distal edge of the band (Figs 24, 26), and there are no external pores (Crawford, 1977).

Other marine species studied under the SEM are $M$. arctica and M. nummuloides (Heimdal, 1973, Crawford, 1975, Syvertsen \& Hasle, 1988). In both species, the loculi are predominantly quadrangular and of equal size (Fig. 31). The rotae are irregularly arranged in $M$. nummuloides, but are in radial rows in $M$. arctica (Fig. 30), as occurs in $M$. brandinii. Fewer rimoportulae appear on the valve face and the mantle of $M$. nummuloides and $M$. arctica (Figs 27-28, Heimdal, 1973, Crawford, 1974) compared to $M$. brandinii. The internal opening of the rimoportula of $M$. arctica is a fissure projected from the surface and with a thickened rim (Figs 29-30), while it is simple in $M$. brandinii. In addition, $M$. nummuloides and $M$. arctica possess carina, which are absent in $M$. brandinii. All these characteristics clearly distinguish the two species from $M$. brandinii. Conversely, the identity of $M$. arctica seems to be more problematic. Syvertsen \& Hasle (1988) found three morphotypes when studying samples from the Canadian Arctic (Melville Bay, analyzing the type material of Dickie),
Oslofjord and Baltic Sea. The main differences between the morphotypes were in the valvar diameter and shape, the presence/absence of corona, and the number of rimoportulae on the valvar surface and near the mantle edge. The authors proposed that the specimens found could be included in the circumscription of $M$. arctica, but with enough unique characteristics to designate them at a varietal level. In our work, we provide photomicrographs of the type material from Melville Bay (Figs 27-31, 3435 ), and of material sampled in the Barents Sea (Figs 32-33) kindly made available by Drs G. R. Hasle and E. E. Syvertsen. Both of these correspond to the 'Arctic' morphotype described in Syvertsen \& Hasle (1988), due to the presence of a similar number of rimoportulae (32-40) on the valvar face and at the mantle edge, i. e., the marginal ring (6-7 in $10 \mu \mathrm{m})$. Additionally, the distance from edge of the marginal rimoportulae $(<0.7 \mu \mathrm{m})$ is the same for both. Nevertheless, despite the morphological variation observed for $M$. arctica, all morphotypes are entirely distinctive from $M$. brandinii.

Other three species of Melosira also found in Antarctica by early authors deserved further consideration. Melosira octagona A. Schmidt is smaller than $M$. brandinii and its silica walls are very thicker with straight sides (Schmidt, 1874-1959, Pl. 182, Figs 19-21). In Melosira dubia Kützing the valve face and mantle have an almost hyaline appearance, and there is no separation between the valve face and the mantle, that is, the valve lacks corona (Van Heurck, 1880-1885; Schmidt, 18741959; Peragallo \& Peragallo, 1897-1908; Hustedt, 1927-1966; Frenguelli, 1935). In $M$. brandinii these regions are well distinguishable one from the another. Lastly, M. charcotii M. Peragallo is a small diatom (less than $18 \mu \mathrm{m}$ diameter) found by Peragallo (1921) in subantarctic islands. This species has a very delicate structure on the valvar surface, not visible under conventional light microscopy (Peragallo, 1921; Frenguelli \& Orlando, 1958).

The diatom community associated with the colonies of $M$. brandinii is being investigated elsewhere, so only a brief comment is furnished below. The in vivo observations revealed that the cells are a substratum for the attachment of a diverse microbial assemblage. Species of the genera Licmophora, Navicula, Parlibellus and Synedropsis were recorded in high numbers, either at the base of the chains or epiphytic on frustules. Some filamentous phaeophyceans and chlorophyceans were also found. Many ciliates and flagellates were observed, some of them feeding on small Navicula glaciei Van Heurck and other naviculoid diatoms. 

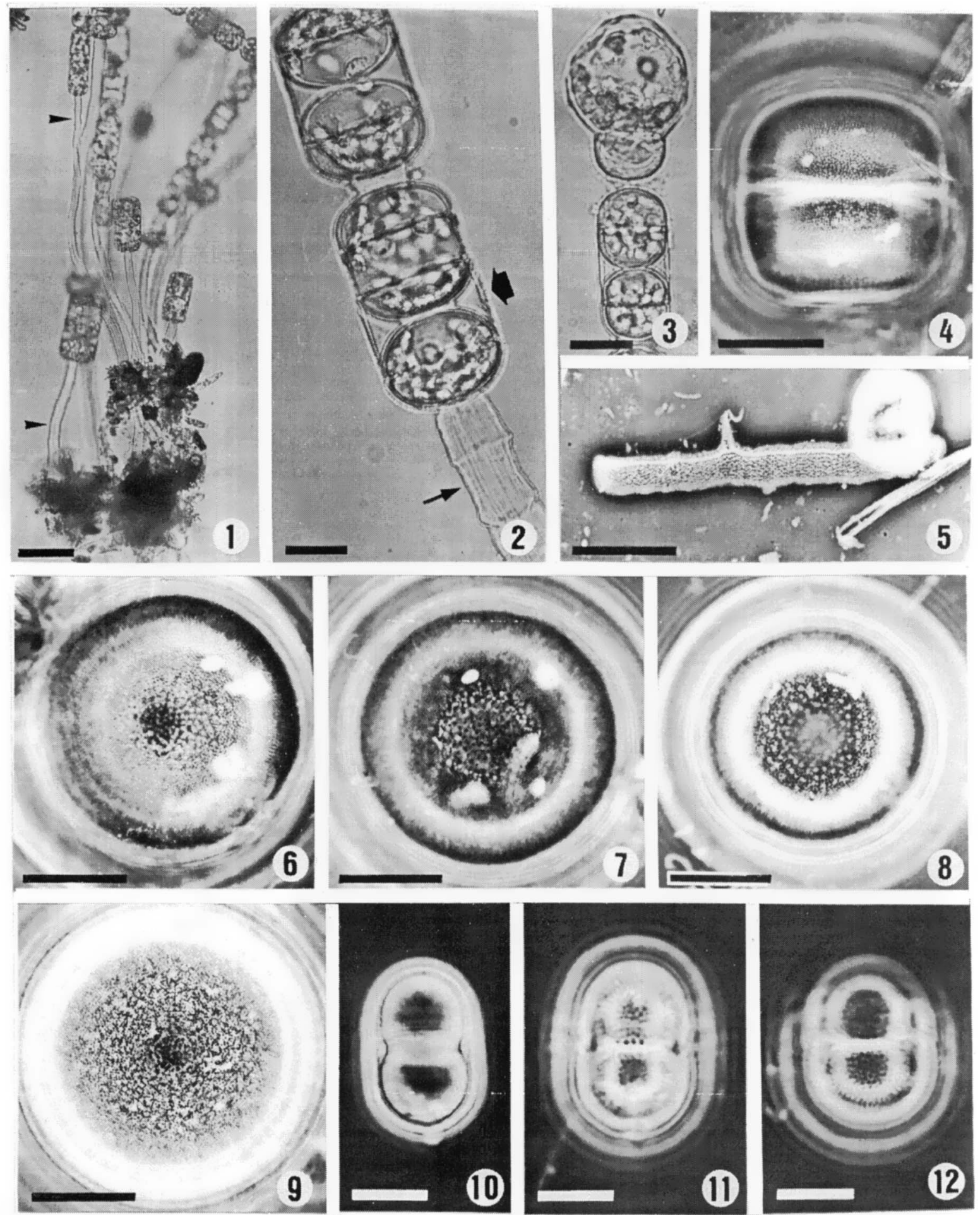

Figs 1-12. Light photomicrographs of Melosira brandinii from Elephant Island, Antaretica. Figs 1-3. Formaldehyde fixed material. Figs 4-12. Cleaned material, holotype slide.

Fig. 1. Colonies with cells in girdle view, showing the long mucilage stalks (arrowheads). Scale= $100 \mu \mathrm{m}$. Fig. 2 . Detail of frustule in girdle view to illustrate pseudosulcus (large arrow) and mucilage stalks (thin arrow) bearing longitudinal striations. Scale $=20 \mu \mathrm{m}$. Fig. 3. Terminal auxospore. Scale $=20 \mu \mathrm{m}$. Fig. 4. Frustule in girdle view. Scale $=20 \mu \mathrm{m}$. Fig. 5 . A band of the cingulum. Note hyaline strip at the edge. Scale $=20 \mu \mathrm{m}$. Fig. 6 . Valve view showing annulus around the valve face, and granules and loculi on the mantle. Scale $=20 \mu \mathrm{m}$. Fig. 7. Valve view. Note rimoportula openings on the valve face, and the corona composed of granules. Scale $=20 \mu \mathrm{m}$. Fig. 8. Valve view, illustrating granules on the mantle. Scale $=20 \mu \mathrm{m}$. Fig. 9 . Valve view of slightly silicified valve. Note annulus at the center. Scale $=20 \mu \mathrm{m}$. Figs 10-12. Preauxospore cell in girdle view at different focal planes. Scales $=20 \mu \mathrm{m}$. 

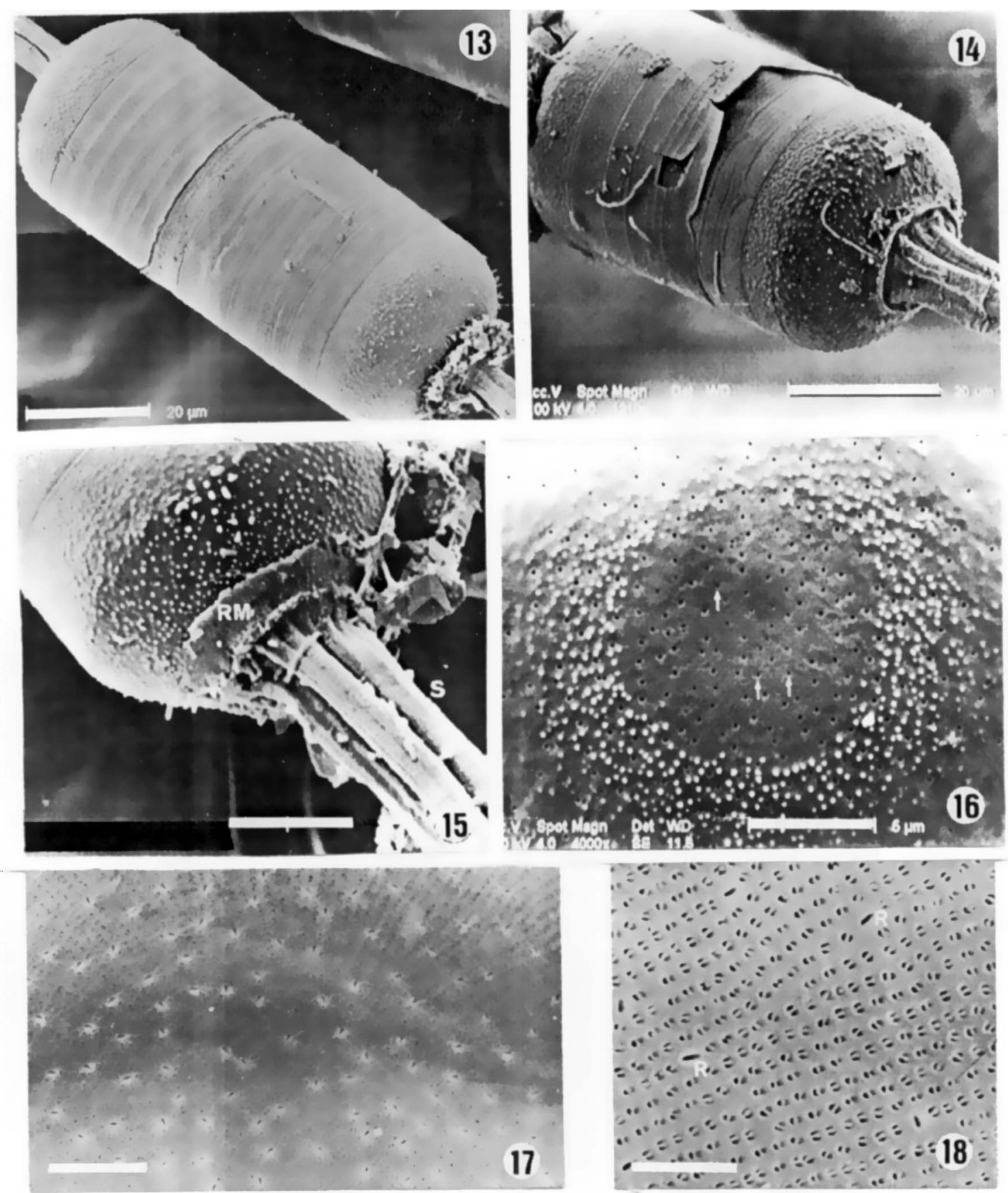

Figs 13-18. Scanning electron micrographs of Melosira brandinii in external (Figs 13-16) and internal (Figs 17-18) views.

Figs 13-14. Whole frustules in girdle view showing bands of the cingulum. Note ring of mucilage and stalk at the apices. Scales= $20 \mu \mathrm{m}$. Fig. 15. Detail of frustule, indicating the ring of mucilage (RM). Note longitudinal striations of the stalk (S). Scale= $10 \mu \mathrm{m}$. Fig. 16. External valvar surface, detail of center. The circular openings of rimoportulae (arrows) on the valve center are encircled by a corona of granules. Scale $=5 \mu \mathrm{m}$. Fig. 17. General view of the central region with rimoportulae and rotae. $\mathrm{Scale}=2 \mu \mathrm{m}$. Fig. 18. Radial arrangement of rotae on the mantle. Rimoportulae $(\mathrm{R})$ also respect that pattern. Scale $=1 \mu \mathrm{m}$. 

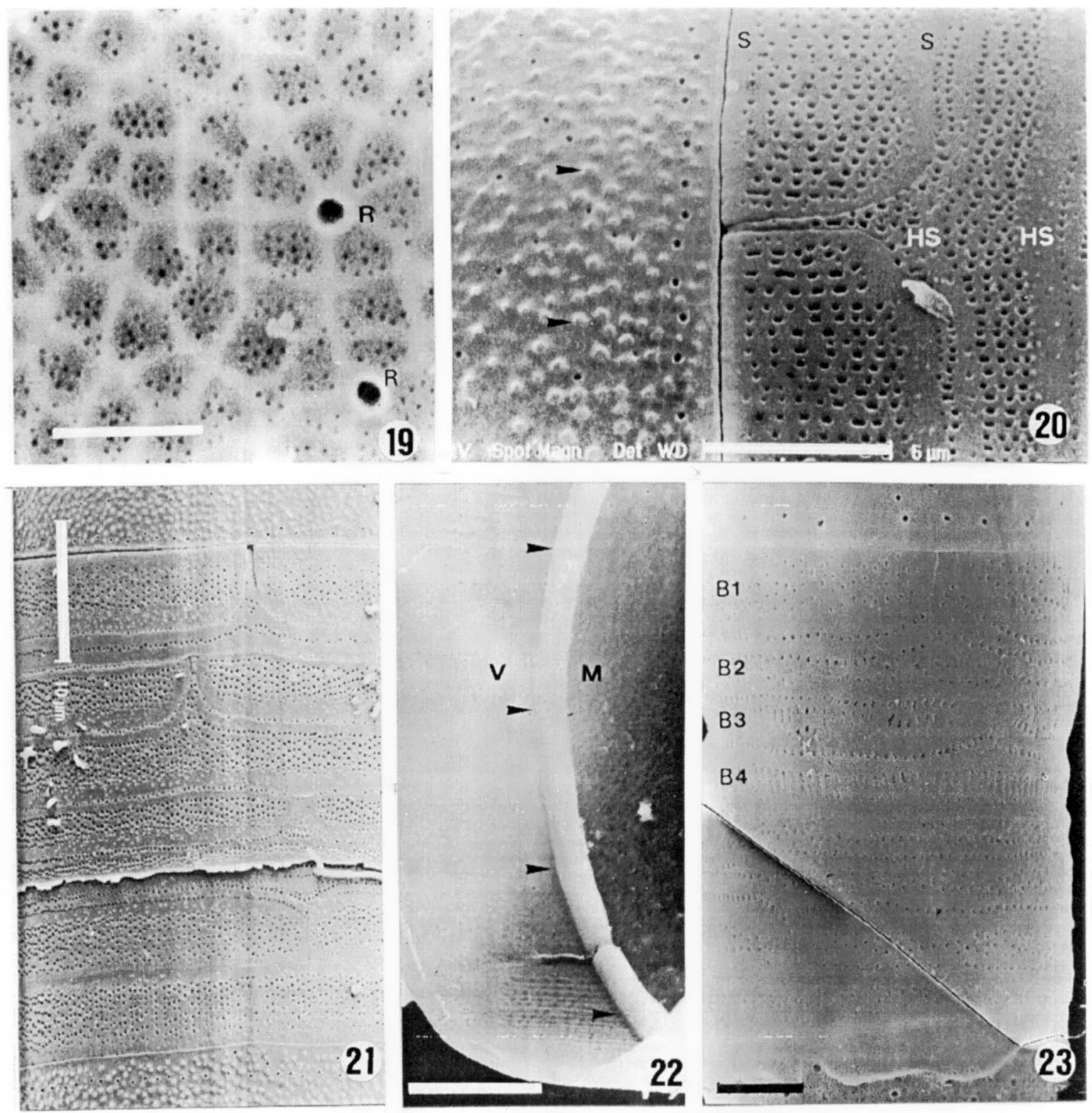

Figs 19-23. Scanning electron micrographs of valve (Fig. 22) and frustules (Figs 19-21, 23) of Melosira brandinii.

Fig. 19. Pores of loculi in external view, bordered by silica ridges. External openings of rimoportulae are indicated $(R)$. Scale $=1$ $\mu \mathrm{m}$. Fig. 20. Detail of the valvar mantle with granules (arrowheads) and ring of rimoportulae at the edge. Cingulum is also illustrated, indicating the hyaline strip (S) of the valvocopula and of the next band (HS). Scale $=5 \mu \mathrm{m}$. Fig. 21 . General view of cingulum in a large frustule. Scale $=10 \mu \mathrm{m}$. Fig. 22. Internal valve view of mantle (M) and valvocopula (V). Arrowheads indicate the rectangular thickening on the mantle edge. Scale $=5 \mu \mathrm{m}$. Fig. 23. Enlargement of the same specimen, detailing bands of the epicingulum (B1-B4). Note elongated pores at the third (B3) and fourth (B4) bands. Scale $=2 \mu \mathrm{m}$. 

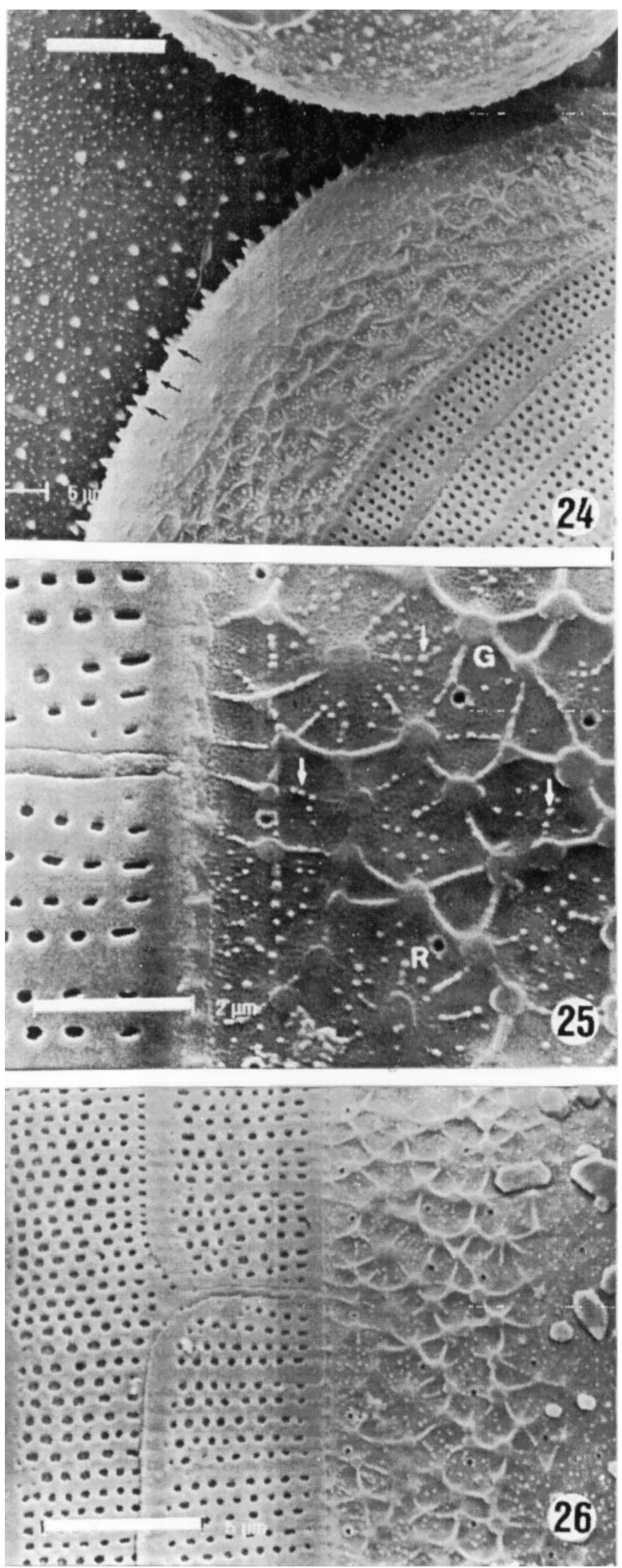

Figs 24-26. Melosira moniliformis from Southern Brazil. Scanning electron micrographs, external views.

Fig. 24. Two different valves in lateral view, showing spines on their surfaces (arrows), and granules near the valvar margin. Scale $=5 \mu \mathrm{m}$. Fig. 25. Detail of mantle edge bearing robust granules $(G)$ with elongated basal thickenings, and external openings of rimoportulae (R) surrounded by a raised rim. Arrows indicate small granules. Note the pores over the valve surface. Scale= $2 \mu \mathrm{m}$. Fig. 26. Frustule in girdle view, showing cingulum and valve margin. Note the circular pores arranged in transverse rows. The second band has no hyaline strip near the valvocopula. Scale $=5 \mu \mathrm{m}$. 

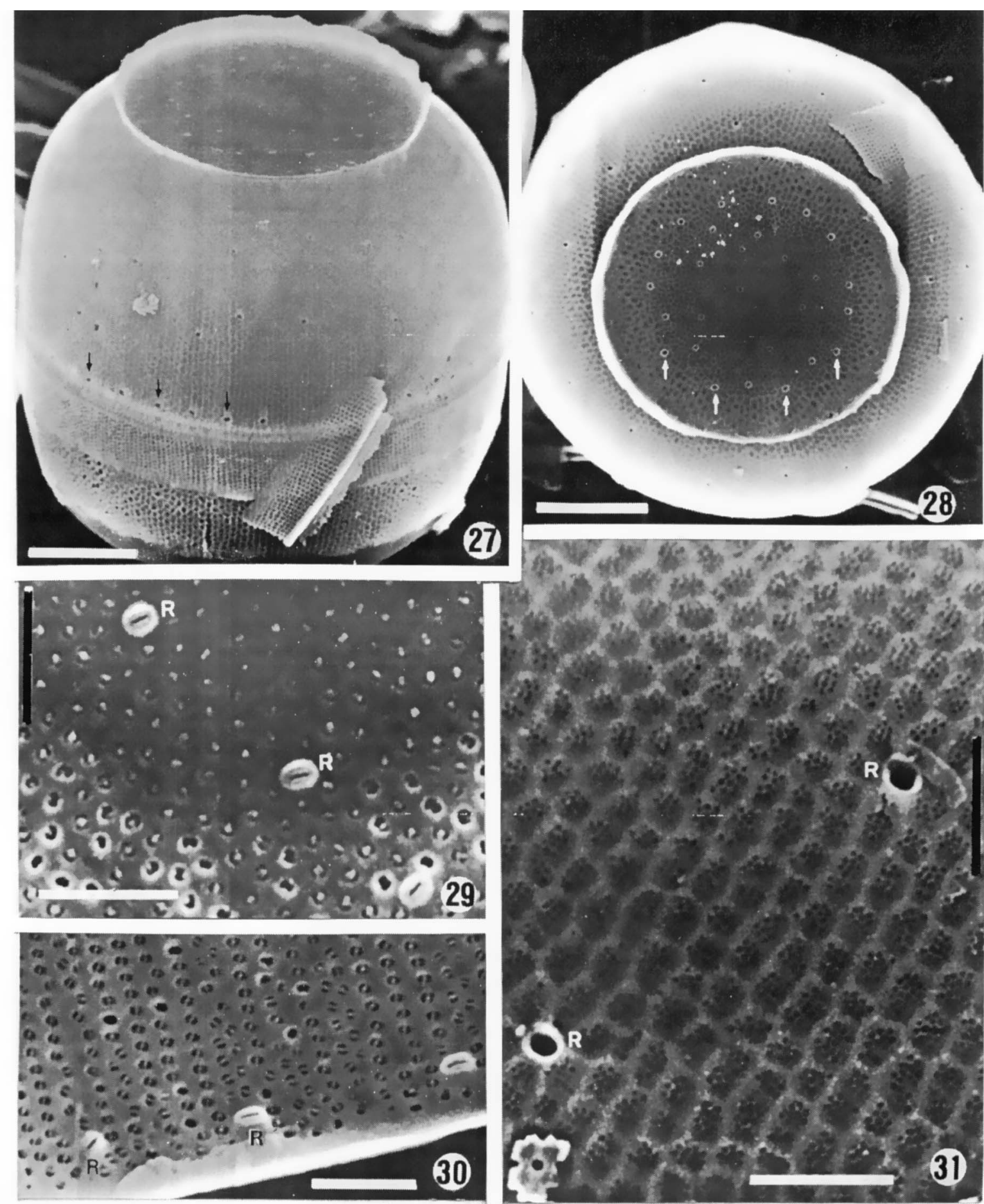

Figs 27-31. Scanning electron micrographs of Melosira arctica from Melville Bay, Canadian Arctic, type material.

Fig. 27. Entire frustule. Arrows indicate marginal ring of rimoportulae. Scale $=1 \mu \mathrm{m}$. Fig. 28. External valve surface with conspicuous carina encircling a portion of the mantle and the valve face. Note rimoportulae (arrows). Scale=1 $\mu \mathrm{m}$. Fig. 29. Internal valve surface, illustrating rimoportulae $(R)$ on the mantle. Rotae are eroded. $\mathrm{Scale}=1 \mu \mathrm{m}$. Fig. 30. Internal valve edge, showing the marginal ring of rimoportulae $(\mathrm{R})$, and the radial arrangement of rotae. Scale $=1 \mu \mathrm{m}$. Fig. 31. External valve view, showing loculi and their grouped cribral pores. Rimoportulae $(R)$ are indicated. Scale $=1 \mu \mathrm{m}$. 


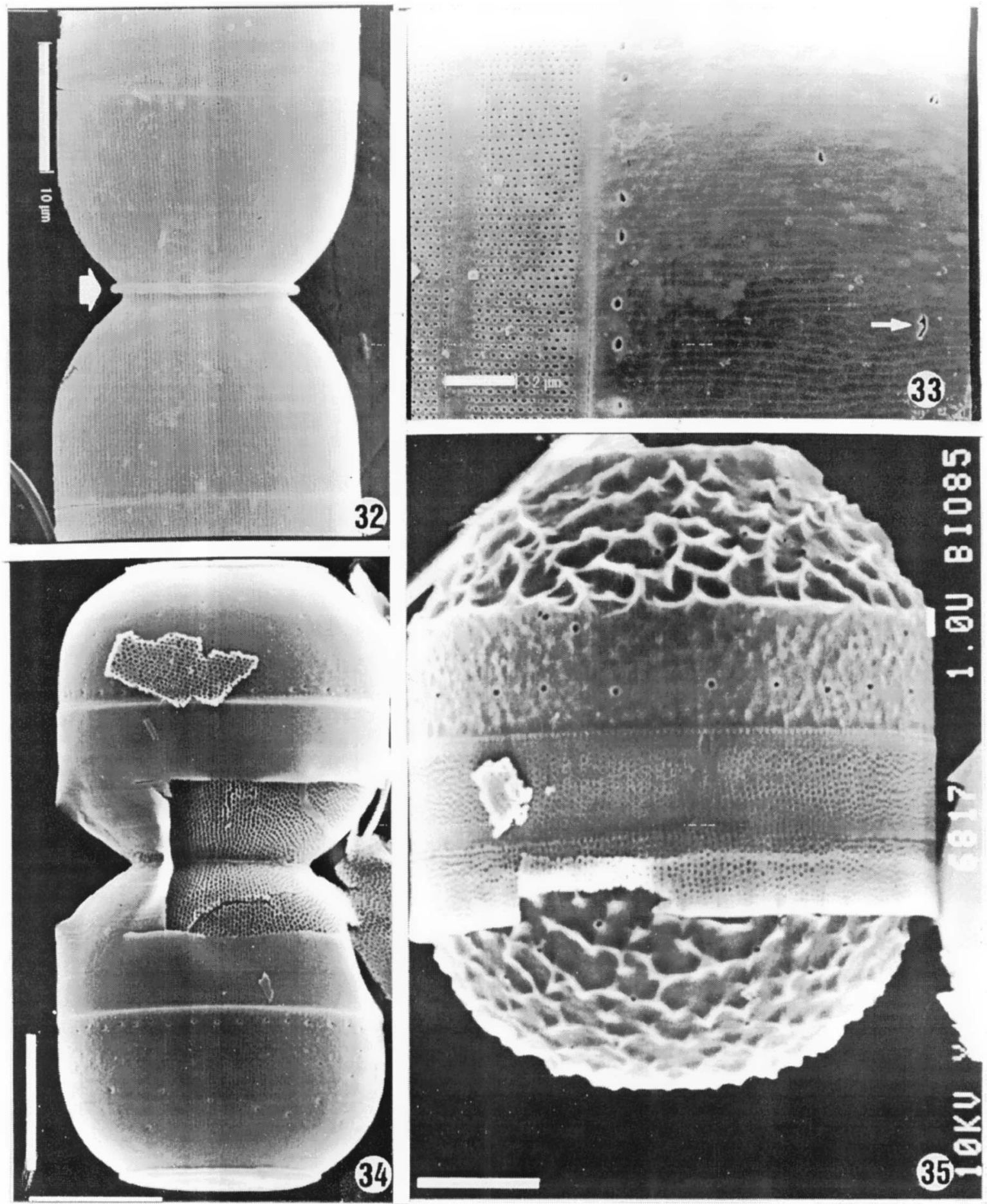

Figs 32-35. Scanning electron micrographs of Melosira arctica from Barents Sea (Figs 32-33) and Melville Bay, type material (Figs 34-35).

Fig. 32. Lateral view of two different valves. Note mode of junction of the carina (arrow). Scale $=10 \mu \mathrm{m}$. Fig. 33. External lateral view of cingulum and mantle. Cingulum has numerous pores. The marginal ring of rimoportulae is also visible at the mantle edge. Arrow indicates an abnormal rimoportula. Scale $=2 \mu \mathrm{m}$. Fig. 34. Frustules in girdle view. Scale $=10 \mu \mathrm{m}$. Fig. 35 . Resting spore in girdle view. Note modifications of the valve surface, and the marginal ring of rimoportulae. Scale $=4 \mu \mathrm{m}$. 


\section{Acknowledgements}

Dr Grethe Hasle and Dr Erik Syvertsen (University of Oslo, Norway) kindly sent SEM pictures of type material, and Barents Sea samples of Melosira arctica. M.Sc. Ricardo L. Abrão helped with the sampling. The crew of Brazilian Navy ship 'Ary Rongel' was always ready to aid. Dr Daura R. Stofella (Centro de Microscopia Eletrônica/UFPR) and Dr Maurício P. Cantão (Instituto de Tecnologia para o Desenvolvimento (LACTEC/Paraná) assisted in using of the SEM. Dr James J. Roper (visitor professor/UFPR) reviewed the English version of the manuscript. This work was funded by CNPq/PROANTAR contract n. 670001/93-7, and FUNPAR/UFPR.

\section{References}

Cleve, P. T. 1883. Diatoms collected during the expedition of the Vega. Vega-Expedition Vetenskap. Iakttag., 3:457-517.

Crawford, R. M. 1971. The fine structure of the frustule of Melosira varians C.A. Agardh. Br. J. Phycol., 6:175-186.

Crawford, R. M. 1974. The structure and formation of the siliceous wall of the diatom Melosira nummuloides (Dillw.) Ag. Nova Hedwigia, 45:131-141.

Crawford, R. M. 1975. The taxonomy and classification of the diatom genus Melosira C. A Agardh. I. The type species $M$. nummuloides C. Ag. Br. Phycologia, 10:323-338.

Crawford, R. M. 1977. The taxonomy and classification of the diatom genus Melosira C. A Agardh. II. M. moniliformis (Müll.) C. Ag.. Phycologia, 16(3):277-285.

Crawford, R. M. 1978. The taxonomy and classification of the diatom genus Melosira C. A Agardh. III. Melosira lineata (Dillw.) C. A. Ag. Phycologia, 17(3):237-250.

Crawford, R. M. 1979. Filament formation in the diatom genera Melosira C.A. Agardh and Paralia Heiberg. Nova Hedwigia, 64:121-133.

Fernandes, L. F.; Brandini, F. P.; Gutseit, K. S.; Fonseca, A. L. \& Pellizzari, F. M. 1999. Benthic diatoms growing on glass slides in the Paranaguá Bay, Southern Brazil: taxonomic structure and seasonal variation. Insula, 28:53-100.
Ferreira, S. \& Seeliger, U. 1985.The colonization process of algal epiphytes on Ruppia maritima L. Botanica mar., 28(6):245-249.

Frenguelli, J. 1935. Melosira dubia en el Platense de la provincia de Buenos Aires. Notas Mus. La Plata, 1:35-44.

Frenguelli, J. \& Orlando, H. A. 1958. Diatomeas y silicoflagelados del sector Antártico Sudamericano. Buenos Aires, Instituto Antartártico Argentino. Publ. No. 5 191p.

Hasle, G. R. \& Fryxell, G. A. 1970. Diatoms: cleaning and mounting for light and electron microscopy. Trans. Am. microsc. Soc., 89(4):469474.

Heiden, H. \& Kolbe, R. W. 1928. Die marinen Diatomeen der deutschen Südpolar-Expedition 1901-1903. Deutsche Südpolar-Exped., 8(heft V):450-715.

Heimdal, B. R. 1973. The fine structure of the frustules of Melosira nummuloides and $M$. arctica (Bacillariophyceae). Norw. J. Bot., 20(23):132-149.

Hustedt, F. 1927-1966. Die Kieselalgen Deutschlands, Österreichs und der Schweiz mit Berücksichtigung der übrigen Ländern Europas sowie der angrenzenden Meeresgebiete. In: L. Rabenhorst Kryptogamenflora, 7(3):1-816.

Hustedt, F. 1958. Diatomeen aus der Antartiks und der Südatlantik. Deutschen Antarktischen Expedition 1938/39, Band 2. Hamburg, Geogr.Kartogr. Anstalt "Mundus". p. 103-191.

Karsten, G. 1906. Das phytoplankton des Antarktischen Meeres nach dem Material der deutschen Tiefsee-Expedition 1898-1899. Deutsche Tiefs.-Exp. II, 2:1-136.

Mangin, L. 1915. Phytoplankton de l'Antarctique. Deuxième Expedition Antarctique Française (1908-1910). Paris, Masson et Cie. 95p.

Manguin, E. 1960. Les diatomées de la Terre Adélie campagne du "Comandant Charcot" 1949-1950. Ann. Sci. Nat., Bot., 12:223-363.

Peragallo, H. \& Peragallo, M. 1897-1908. (Reimpression 1965). Diatomées marines de France et des districts voisins: planche. Amsterdam, Asher e Co. 491 pp. +137 plates. 
Peragallo, M. 1921. Diatomées d'eau douce et Diatomées d'eau salée. Deuxième Expedition Antarctique Francaise (1908-1910), commandée par J. Charcot. Sciences naturelles: documents scientifiques, botanique. $38 \mathrm{p}$.

Rendall, D. A. \& Wilkinson, M. 1983. The seasonal and spacial distribution of attached Melosira species in the upper Clyde estuary, Scotland. Botanica mar., 26(5):249-253.

Ross, R.; Cox, E. J.; Karayeva, N. I.; Mann, D. G.; Paddock, T. B. B.; Simonsen, R. \& Sims, P. A. 1979. An amended terminology for the siliceous components of the diatom cell. Nova Hedwigia, 64:513-533.

Round, F. E.; Crawford, R. M. \& Mann, D. G. 1990. The Diatoms. biology and morphology of the Genera. Cambridge, Cambridge University Press. $747 \mathrm{p}$.

Schmidt, A. 1874-1959. Atlas der Diatomaceenkunde. Leipzig, O. R. Reisland. 480p.
Simonsen, R. 1979. The diatom system: ideas on phylogeny. Bacillaria, 2:9-71.

Syvertsen, E. \& Hasle, G. H. 1988. Melosira arctica in the Baltic sea and in the Oslofjord (a preliminary note) In: Miller, U. \& Robertsson, A.M. eds. In: PROCEEDINGS OF NORDIC DIATOMIST MEETING. Stockholm, 1987. University of Stockholm, Department of Quaternary Research. Report, 12:79-84.

Van Heurck, H. 1880-1885. Synopsis des diatomées de Belgique. Anvers, Édite par l'auteur. 2v.

Van Heurck, H. 1909. Diatomées. Resultats du voyage du S.Y. "Belgica" en 1897-1899 sous le commandetement de Adrien de Gerlache du Gomery. Rapports Scientifiques: Botaniques. Exped. Antarct. Belg., 5:1-129.

(Manuscript received 20 February 2001; revised 28 May 2001; accepted 16 October 2001) 